UDC 621.391.823

V. Makarenko, PhD, Assoc. Prof., O. Lukashev

National Technical University of Ukraine “Igor Sikorsky Kyiv Polytechnic Institute”, 37 Peremohy Ave., Kyiv, Ukraine, 03056; e-mail: alexlukashew@gmail.com

\title{
ANALYSIS OF THE INFLUENCE OF THE POWER FACTOR CORRECTOR ON THE LEVEL OF ELECTROMAGNETIC INTERFERENCE OF AC/DC CONVERTERS
}

В.В. Макаренко, О.Ю. Лукашев. Аналіз впливу коректора коефіцієнта потужності на рівень електромагнітних завад AC/DC-перетворювачів. У статті приведені результати дослідження імпульсного джерела живлення від мережі змінного струму 220 В/50 Гц, що складається з коректора коефіцієнта потужності та понижуючого DC/DC-перетворювача. Запропонована в роботі модель джерела, розроблена для роботи в середовищі LTspice, дозволяє досліджувати коефіцієнти потужності, нелінійних спотворень мережевого струму, корисної дії, а також спектри кондуктивних завад, що створюються при роботі джерела. Ефективність запропонованої моделі підтверджується тим, що вона забезпечує ефективну роботу джерела в діапазоні вхідної напруги від 128 до 400 В. Дослідження моделі джерела з коректором коефіцієнта потужності проводились із використанням незалежних систем автоматичного управління ключами коректора коефіцієнта потужності та понижуючого DC/DC-перетворювача, що дозволило провести дослідження рівня кондуктивних завад, створюваних імпульсним джерелом живлення, від частоти комутації силових ключів кожного з вузлів, від ефективності використання технології розмиття спектру сигналу управління коректором коефіцієнта потужності та DC/DC-перетворювачем. Порівняння ефективності здійснювалось за рівнем спектральних складових у спектрі струму мережі від якої здійснюється живлення джерела. Проведені дослідження показали доцільність використання технології розмиття спектру у DC/DC-перетворювачі. Ефективність використання цієї технології по зменшенню кондуктивних завад складає від 8 до 10 дБ, в залежності від параметрів джерела живлення. В роботі показано, що вибір частоти комутації силових ключів коректора коефіцієнта потужності та DC/DC-перетворювача слід проводити шляхом моделювання при включеному режимі розмиття спектру в перетворювачі. Показано, що невірний вибір частоти сигналів управління ключами коректора коефіцієнта потужності та DC/DC-перетворювача може призвести до збільшення рівня кондуктивних завад на 10 дБ. Аналіз моделей джерела живлення та окремих його вузлів дозволяє обгрунтовано здійснювати як вибір частоти комутації силових ключів джерела живлення від мережі змінного струму, так і використання ефективних методів зниження електромагнітних завад, що створюються при роботі імпульсних джерел живлення. Отримані результати дозволяють оцінити не тільки потенційні можливості різних методів зниження рівня електромагнітних завад при варіації параметрів сигналів управління силовими ключами вузлів перетворювача, а і сформувати рекомендації по комбінації цих методів для отримання найкращого результату.

Ключові слова: кондуктивна завада, спектр, розширення спектру, Spread Spectrum, перетворювач, модуляція, корекція, моделювання, стабілізатор, нелінійні спотворення

$V$. Makarenko, $O$. Lukashev. Analysis of the influence of the power factor corrector on the level of electromagnetic interference of AC/DC converters. The article presents the results of a study of a $220 \mathrm{~V} / 50 \mathrm{~Hz}$ AC power source consisting of a power factor corrector and a DC/DC converter. The proposed model of the source, designed to work in the LTspice environment, allows you to investigate the power factors, nonlinear distortions of the network current, efficiency, as well as the spectra of the conductive interference generated during the operation of the source. The efficiency of the proposed model is confirmed by the fact that it provides efficient operation of the source in the range of the input voltage from 128 to $400 \mathrm{~V}$. The studies of the power factor correction source model were conducted using independent automatic power factor correction key control systems and a DC/DC converter, which made it possible to study the level of conductive interference generated by the impulse power source from the power switching frequency of each key from the efficiency of the power keys the use of blurring of the spectrum of the signal of correction of the power factor and the DC/DC converter. Efficiency comparisons were made on the level of spectral components in the current spectrum of the network from which the source is supplied. Studies have shown the feasibility of using spectrum blurring technology in DC/DC converters. The efficiency of using this technology to reduce conductive interference is from 8 to $10 \mathrm{~dB}$, depending on the power source parameters. It is shown in the paper that the selection of the switching frequency of the power factor correction key switches and the DC/DC converter should be made by simulation with the blur mode in the converter on. It has been shown that incorrect frequency selection of the power factor correction key and DC/DC converter key leads to a $10 \mathrm{~dB}$ increase in conductive interference. The analysis of the models of the power source and its individual units makes it possible reasonably make both the choice of the switching frequency of the power switches of the power source from the AC power source and the use of effective methods of reducing the electromagnetic interference created during the operation of the pulse power sources. The results obtained allow us to evaluate not only the potential of different methods of reducing the level of electromagnetic interference in the variation of the parameters of the control signals of the power keys of the converter nodes, but also to formulate recommendations on the combination of these methods for the best result. distortions

Keywords: conductive interference, spectrum, Spread Spectrum, converter, modulation, correction, modeling, stabilizer, nonlinear

\section{DOI: 10.15276/opu.3.59.2019.10}

(c) 2019 The Authors. This is an open access article under the CC BY license (http://creativecommons.org/licenses/by/4.0/). 
Introduction. When designing AC to DC (AC/DC converters), not only the maximum efficiency, but also low electromagnetic interference and small distortion of the current consumed by the network must be achieved.

While the problems of reducing electromagnetic interference created during the operation of DC/DC converters have been considered in many papers [ $1-4]$, the problems of creating electromagnetic interference by power factor correctors (PFC) included in the AC/DC converters have hardly been considered. The problem is compounded by the fact that in addition to the power factor corrector, the AC/DC converter also includes a DC/DC converter, which typically works with a key switch different from the power factor corrector (PFC). Therefore, in addition to investigating the methods of reducing electromagnetic interference generated by the power factor correction, at least two more questions must be answered. The first is whether you can make the same switching frequency of the power factor corrector and the DC/DC converter. And if not, the second question is what is the ratio between the switching frequencies of these devices that will give you a minimum level of electromagnetic interference.

PFC can be implemented as passive, in the form of LC-filter, and active - in the form of a singlestep boost converter.

Literature data analysis and problem statement. The issues of reducing the conductive noise created by the operation of DC/DC converters are considered in $[1,4]$. They show that the high efficiency of their reduction is provided by the technology of expansion of the spectrum of the switch of the switch of power keys.

However, the question of the interaction of two converters connected in series, as well as the choice and correlation of their parameters in these sources is absent. In addition, important issues such as the impact of spectrum expansion on the efficiency of converters have not been addressed, since the circuits of the converters include power keys that are the source of losses in a typical power source.

Depending on the choice of the operating frequency of the active PFC, the correction methods can be divided into two types - high frequency (if the switching frequency of the corrector power key is much higher than the frequency of the input network) and low frequency correction [5]. Currently, high frequency correction is most often used, the main advantage of which is to reduce the dimensions of the inductor and the converter as a whole, and the high frequency MOSFET transistors make it possible to implement this method with high efficiency.

The parameters of the PFC on the power factor are regulated by the normative document EN 61000-3-2, and the level of interference created by any converters standard CISPR25.

The purpose and objectives of the study. Find ways to reduce conductive electromagnetic noise generated by AC/DC converters by optimizing the parameters of the converters according to the efficiency criteria created in the AC network of the nonlinear distortions and the noise level.

Since impulse energy converters contain not only the power factor corrector but also the DC/DC converter, the design of such a device raises the problem of not only the high efficiency factor but also the low electromagnetic interference generated by the two devices (Fig. 1). Investigation of such parameters as the level of generated electromagnetic interference (depending on the ratio of the switching frequency of the transducer power keys and methods of control signal modulation) and the efficiency of the use of the blurring technology in different links of the pulse power supply will allow to reasonably agree on the parameters of the DC correction parameter. DC/DC converter, to reduce the level of electromagnetic interference at high values of power factor and efficiency.

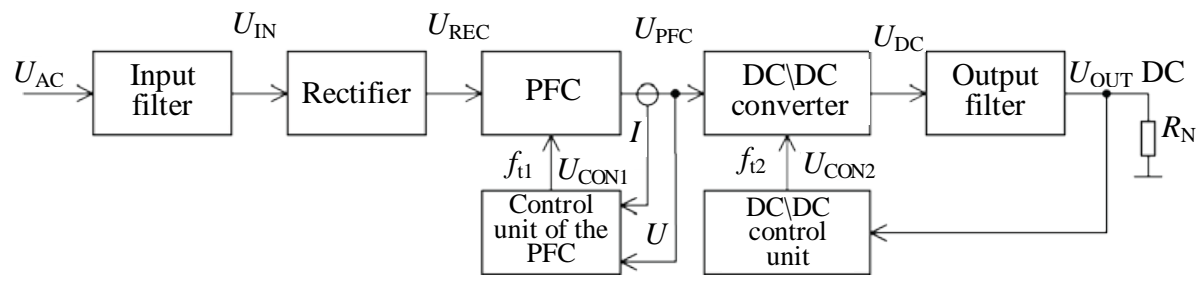

Fig. 1. Functional diagram of a power source with a power factor correction without galvanic isolation 
Materials and methods of research. Power factor correctors are widely used in the construction of power sources and allow to save about $30 \%$ of energy through its more efficient use. The power factor corrector is based on the DC/DC converter (Fig. 1), whose operation is provided by the control unit of the PFC.

The phase difference between the current and voltage signals is determined by the power factor $\cos (\phi)$. For power sources without correction, it is about $60 \%$, with passive correction up to $70 \ldots 75 \%$, and when using an active pulse width modulation (PWM) can exceed $93 \%$.

Another important characteristic of the signal is the coefficient of harmonic distortion KG (in THD - Total Harmonic Distortion), which is equal to the ratio of the rms value of the harmonics (except the first) to the first harmonic. The shift of the current phase relative to the voltage phase and the distortion of the current signal are caused by the presence of nonlinear elements in the pulse power supply. This is basically the capacitance of the rectifier output. The presence of a large capacity at the input of the power source leads to bursts of current consumed, which in turn leads to an increase in the harmonic ratio. Therefore, a power factor correction is required to reduce the bursts of current consumed by the sinusoidal peaks and ensure a uniform load on the network.

Pulse width modulation (PWM) in the control units of both converters is used to control the voltage at the output of the power source and its stabilization, which allows, by changing the duration of the control pulses, to stabilize the output voltage. In order to stabilize the voltage, a voltage feedback in each of the converters is introduced, and in the PFC converter also a current feedback. The ripple of the output voltage is smoothed by the output filter.

In order to analyze the work of the PFC in LTspice XVII environment, a model of step-up converter (Fig. 2) was developed, which works in the power factor correction mode.

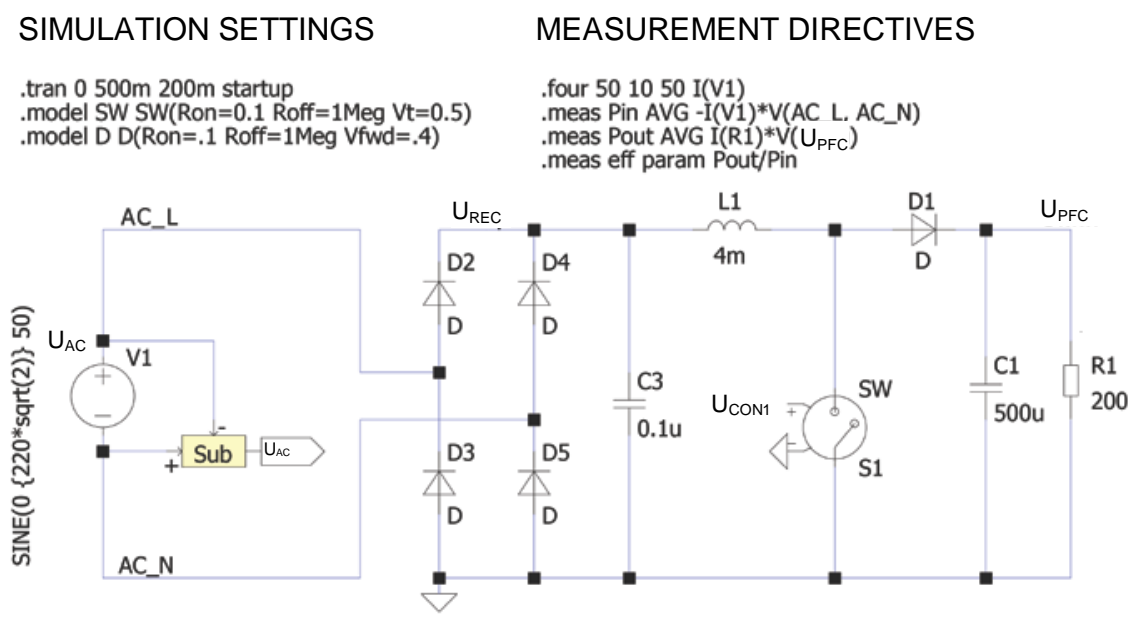

Fig. 2. Power factor correction model

To accelerate the analysis process in the model shown in Fig. 2, idealized elements are used, the parameters of which are not changed by current or voltage, but are set by the user. The beginning and duration of the simulation process, as well as the start time of saving the simulation results, are specified by the .tran directive. The .model directives specify the key (SW) and diode (D) parameters. All models of switches and diodes are perfect, ie their parameters are independent of the voltage applied to them and the current flowing through them. The resistance of the open switches and diodes is 0.1 Ohms and the direct voltage drop is $0.4 \mathrm{~V}$ on the diode.

The .four directive allows you to perform a Fourier analysis for $50 \mathrm{~Hz}$ input signal I (V1) using the first 10 harmonic components to be analyzed. The .meas directive determines the efficiency of the converter by processing the output of the simulation. The result is assigned to the variable eff corresponding to the ratio of the rms value of the power consumed by the load to the power consumed by the AC network - eff $=P_{\text {out }} / P_{\text {in }}$.

The subtraction module (referred to as SUB in Fig. 2) is designed to control the voltage form of the AC mains. 
The proofreader operates in the mode of continuous current (CCM - common conductive mode), that is, in a mode in which during the operating cycle the current through the inductor does not have time to fall to zero. This mode is selected for several reasons. Interrupt mode or limit control method is used in low power sources and its feature is the variable switching frequency of the key which is influenced by the output load and the input voltage. To determine the optimum ratio between the operating frequencies of the PFC and the DC/DC converter, the former must have a constant switching frequency of the key, which is only possible in CCM mode.

The functional diagram of the PFC control unit, which also performs the function of stabilizing the output voltage of the corrector, is shown in Fig. 3.

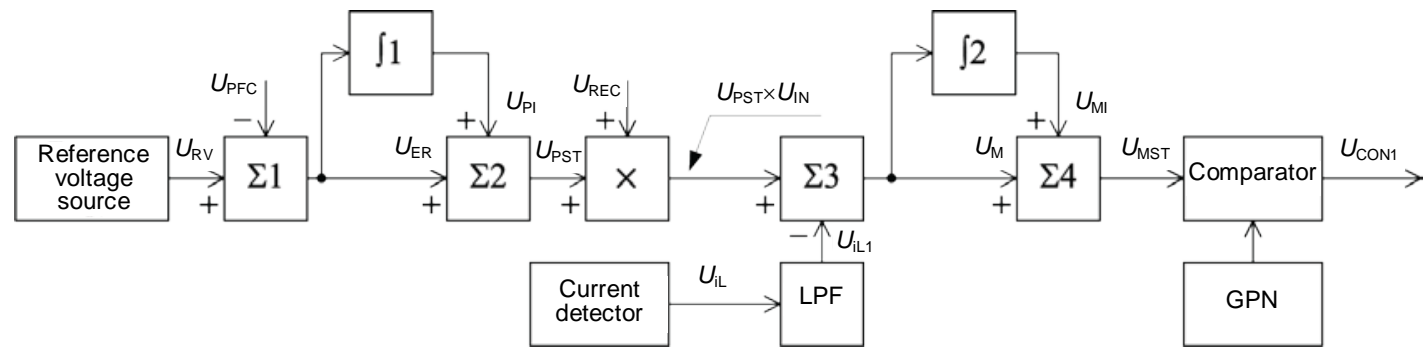

Fig. 3. Functional diagram of the PFC control unit with output voltage stabilization

The PFC control unit is a first-order automatic control system. The control signal of the $\mathrm{U}_{\mathrm{MST}}$ modulator is formed by a system of proportional-integrating type (PI). The $U_{i L}$ signal from the output of the current detector (not shown in Fig. 2), which is connected in series with the inductor L1, through a low-pass filter (LPF) that reduces the effect of harmonic components on the inverter output, is fed to the input of subtractor $\Sigma 3$. The input of the addition of the third adder receives a control signal proportional to the error error $U_{\mathrm{ER}}$, multiplied by the instantaneous value of the rectified voltage $U_{\mathrm{REC}}$. This leads to the fact that the pulse duration at the output of the converter depends not only on the error signal but also on the instantaneous voltage value of the network. Thus, the PFC draws more energy from the network when the network voltage increases and less when the network voltage decreases, which leads to a decrease in the amplitudes of the harmonic components of the current consumed. The component voltages entering the inputs of the third adder can be calculated by the formulas

$$
\begin{gathered}
U_{\mathrm{ER}}=U_{\mathrm{RV}}-U_{\mathrm{PFC}}, \\
U_{\mathrm{PST}}=U_{\mathrm{ER}}+\frac{1}{T_{1}} \int U_{\mathrm{ER}}(t) d(t), \\
U_{i \mathrm{~L}}=\frac{1}{1+T_{2}} \cdot \int U_{i \mathrm{~L} 1} d(t),
\end{gathered}
$$

where $U_{\mathrm{ER}}$ - the error voltage generated at the output of the first adder,

$U_{i L}$ - the voltage at the output of the current detector flowing through the PFC inductor,

$U_{\mathrm{PFC}}$ - the output voltage of the corrector,

$U_{\mathrm{RV}}$ - a reference voltage equal to the average voltage at the output of the PFC.

The voltage generated at the output of the third adder can be calculated by the formula:

$$
U_{\mathrm{M}}(t)=\left(U_{\mathrm{ER}}+\frac{1}{T_{1}} \int U_{\mathrm{ER}}(t) d t\right) \cdot U_{\mathrm{REC}}-\frac{1}{1+T_{2}} \int U_{i \mathrm{~L}}(t) d t,
$$

where $U_{\mathrm{REC}}$ - voltage signal at the output of the rectifier,

$T_{2}$ is the time constant of the low pass filter LPF (proportional-integrating circuit).

The voltage generated at the output of the fourth adder and controls the operation of the pulsewidth modulator (PWM modulator) is calculated by the formula: 


$$
\begin{gathered}
U_{\mathrm{MST}}(t)=\left(U_{\mathrm{ER}}+\frac{1}{T_{1}} \int U_{\mathrm{ER}}(t) d t\right) \cdot U_{\mathrm{REC}}-\frac{1}{1+T_{2}} \int U_{i l}(t) d t+ \\
+\frac{1}{T_{3}} \int\left(\left(U_{\mathrm{ER}}+\frac{1}{T_{1}} \int U_{\mathrm{ER}}(t) d t\right) \cdot U_{\mathrm{REC}}-\frac{1}{1+T_{2}} \int U_{i l}(t) d t\right) d t
\end{gathered}
$$

where $T_{1}, T_{3}$ - integrator time constants,

$U_{\mathrm{MST}}(t)$ - modulator control signal.

The reference frequency is set by the pulse generator via the Tperiod parameter. The model of the control panel of the RCP in the LTspice environment is shown in Fig. 4.

The pulse generator via the Tperiod parameter sets the reference frequency. The model of the control panel of the PFC in the LTspice environment is shown in Fig. 4.

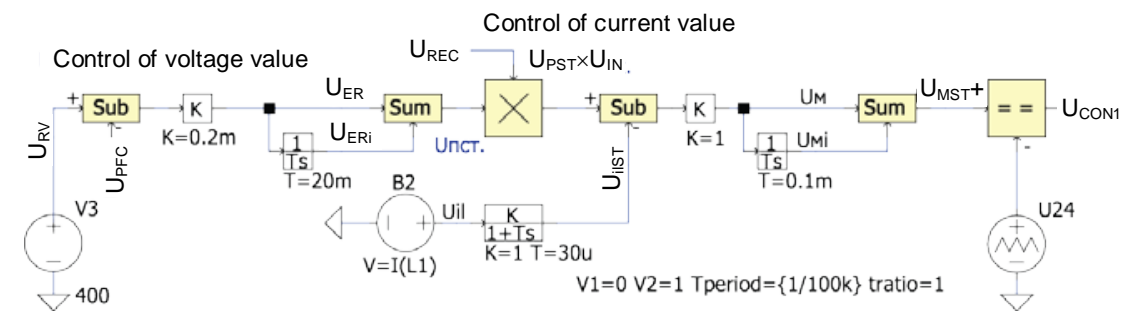

Fig. 4. Model of PFC control unit with output voltage stabilization

The load resistance of the PFC during the study varied from 50 to 200 Ohms. Based on the measurements, a graph of the dependence of the efficiency and the load resistance (Fig. 5) was constructed at a switching frequency of the power key of $200 \mathrm{kHz}$.

As follows from Fig. 5, corrector efficiency decreases with decreasing load resistance. This is explained by the increase in losses on the PFC open key resistance with increasing current, that is, by reducing the load resistance, which is illustrated by the dependence of the efficiency on the resistance at different values of the resistance of the public key Ron.

The coefficient of harmonic distortion of the input current during the experiment did not exceed the value of $4 \%$ (Fig. 6).

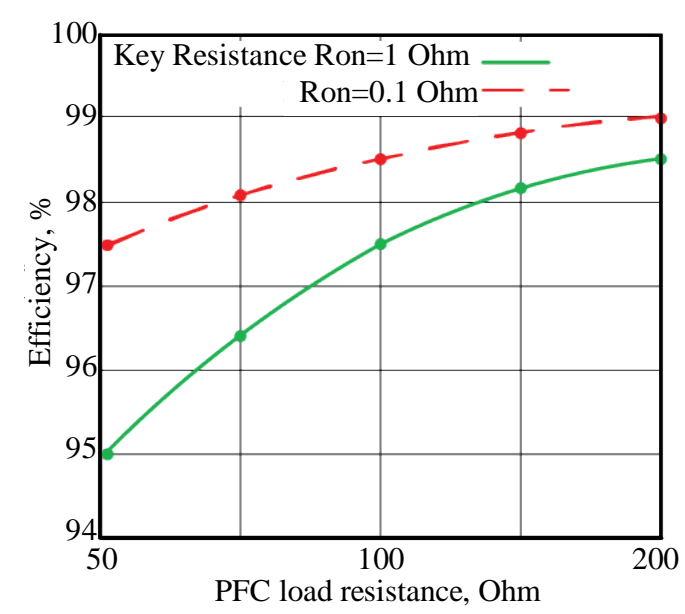

Fig. 5. The dependence of the power factor corrector efficiency on the load resistance at a switching key frequency of $200 \mathrm{kHz}$

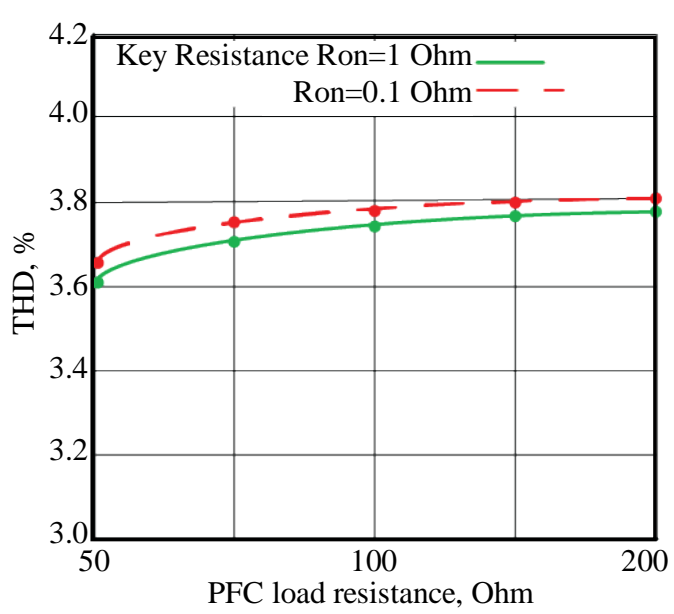

Fia. 6. The dependence of the harmonic distortion coefficient of the current of the corrector network on the load resistance at a switching frequency of $200 \mathrm{kHz}$ key

The forms of voltage and AC signals are shown in Fig. 7.

Table 1 shows the results of measuring the parameters of the PFC when changing the voltage of the AC network. 


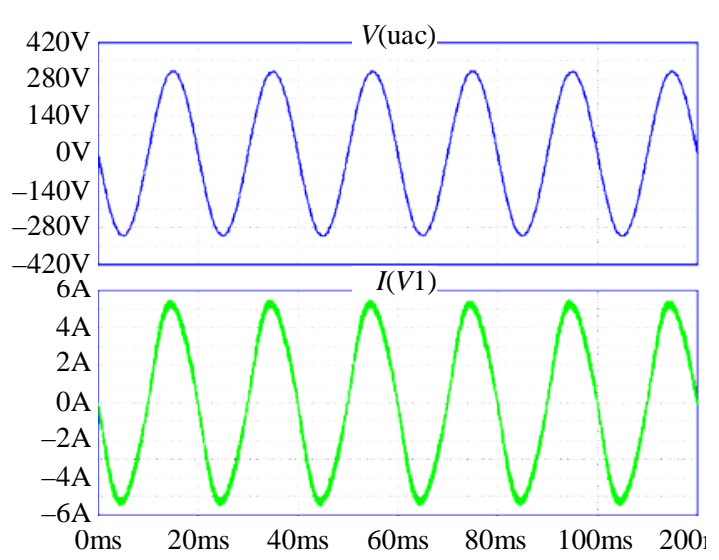

Fig. 7. Forms of voltage (top) and current signals at the input of the PFC

The dependence of the parameters of the power factor corrector on the voltage of the AC network

\begin{tabular}{|c|c|c|c|c|c|}
\hline $\begin{array}{c}\text { Input } \\
\text { voltage, } \\
\text { V }\end{array}$ & $\begin{array}{c}\text { Power } \\
\text { factor, } \\
\%\end{array}$ & $\begin{array}{c}\text { Efficiency, } \\
\%\end{array}$ & \begin{tabular}{|c|} 
The \\
coefficient \\
of \\
harmonic \\
distortion \\
of the \\
network \\
current, \%
\end{tabular} & $\begin{array}{c}\text { PFC } \\
\text { Output } \\
\text { voltage, } \\
\text { V }\end{array}$ & $\begin{array}{c}\text { Output } \\
\text { current } \\
\text { of PFC, } \\
\text { A }\end{array}$ \\
\hline 400 & 99.5 & 98.6 & 6.2 & 400 & 4 \\
\hline 350 & 99.7 & 98.1 & 4.7 & 400 & 4 \\
\hline 312 & 99.8 & 97.4 & 3.76 & 400 & 4 \\
\hline 220 & 99.9 & 93.7 & 1.8 & 400 & 4 \\
\hline 170 & 99.9 & 87.5 & 1.0 & 400 & 4 \\
\hline 128 & 99.9 & 74.0 & 1.0 & 400 & 4 \\
\hline
\end{tabular}

The conducted researches allow to make a conclusion about efficiency and high efficiency of the offered model of PFC in a wide range of change of input voltage. Given this, it is possible to proceed to the analysis of the conductive noise created by the corrector in different modes of operation.

In Figs. 8 and 9 show the input current spectra at 200 and $50 \mathrm{kHz}$ switching frequency and 100 Ohm load impedance. In order to properly compare the effect of operating frequency on the level of electromagnetic interference, it is necessary to change the value of the inductance $L 1$ when changing the switching frequency. The coil inductance values for each frequency-change experiment are calculated in the Power Stage Designer Tool environment.

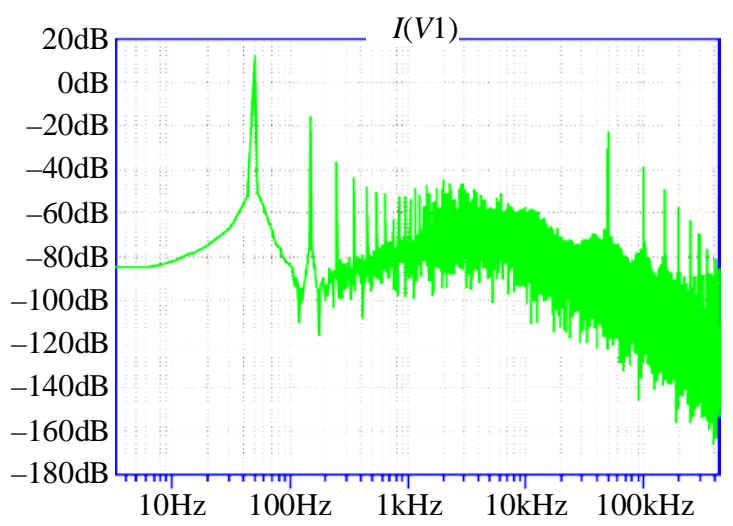

Fig. 8. Spectrum of signal of current of network I (V1) at operating PFC frequency $50 \mathrm{kHz}$ and inductance $L 1=4 m H n$

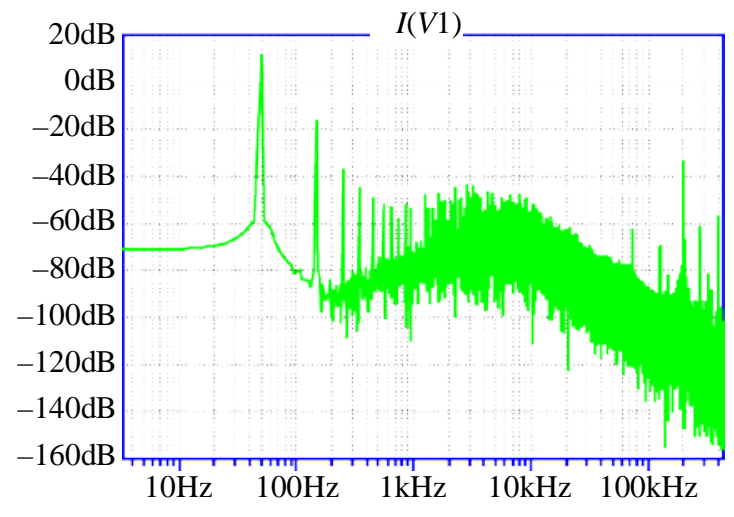

Fig. 9. The current signal spectrum of network I (V1) at an operating PFC frequency of $200 \mathrm{kHz}$ and inductance $\mathrm{L} 1=2 \mathrm{mHn}$

The simulation revealed that the change in the operating frequency of the PFC has virtually no effect on the efficiency and power factor. Comparing the graphs of the spectra in Figs. 8 and 9, it can be concluded that an increase in the switching frequency of the PFC power switch leads to a decrease in the level of spectral components in the low-frequency region of the spectrum, and this parameter should be optimized when designing power sources with low electromagnetic interference.

Since the envelope of the conductive noise spectrum decreases with increasing frequency, and the largest amplitude components of the spectrum are created in the PFC (because it is closer to the input from the AC network), it is advisable to switch the frequency of the power factor corrector keys in the frequency range where the spectrum is interference is significantly reduced. 


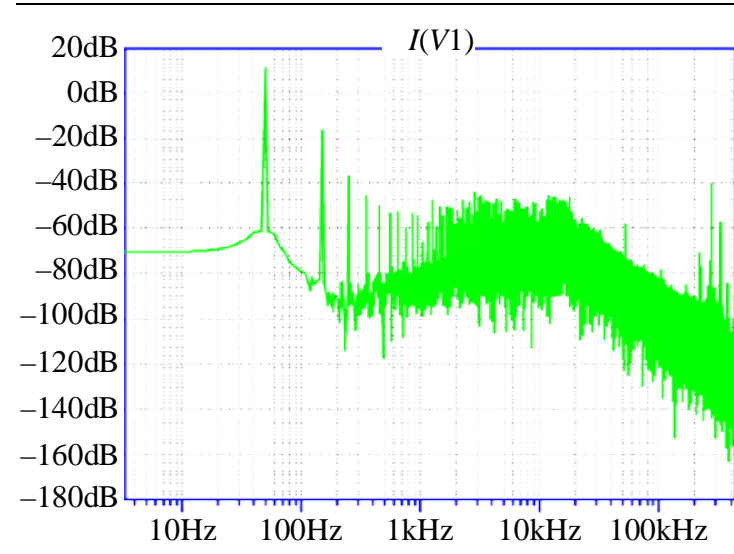

Fig. 10. Spectrum of current signal of network I (V1) at PFC operating frequency $600 \mathrm{kHz}$ and inductance $\mathrm{L} 1=1 \mathrm{mH}$
Fig. 10 shows the spectrum of the current signal at PFC operating frequency of $600 \mathrm{kHz}$, confirming the advanced assumption. The level of the highest component above the frequency of $1 \mathrm{kHz}$ decreased by $5 \mathrm{~dB}$.

The PFC model was supplemented with a DC / DC converter (Fig. 11). All experiments were conducted under the same conditions, namely, with the equivalent of a single-phase network according to the CISPR-22 standard at an effective voltage of the AC $220 \mathrm{~V}$.

The voltage at the output of the source is $140 \mathrm{~V}$ and the load current is $4 \mathrm{~A}$. The voltage pulsations at the output of the down converter are about $0.4 \mathrm{~V}$.

Functional diagram of the control unit downshift converter is shown in Fig. 12.

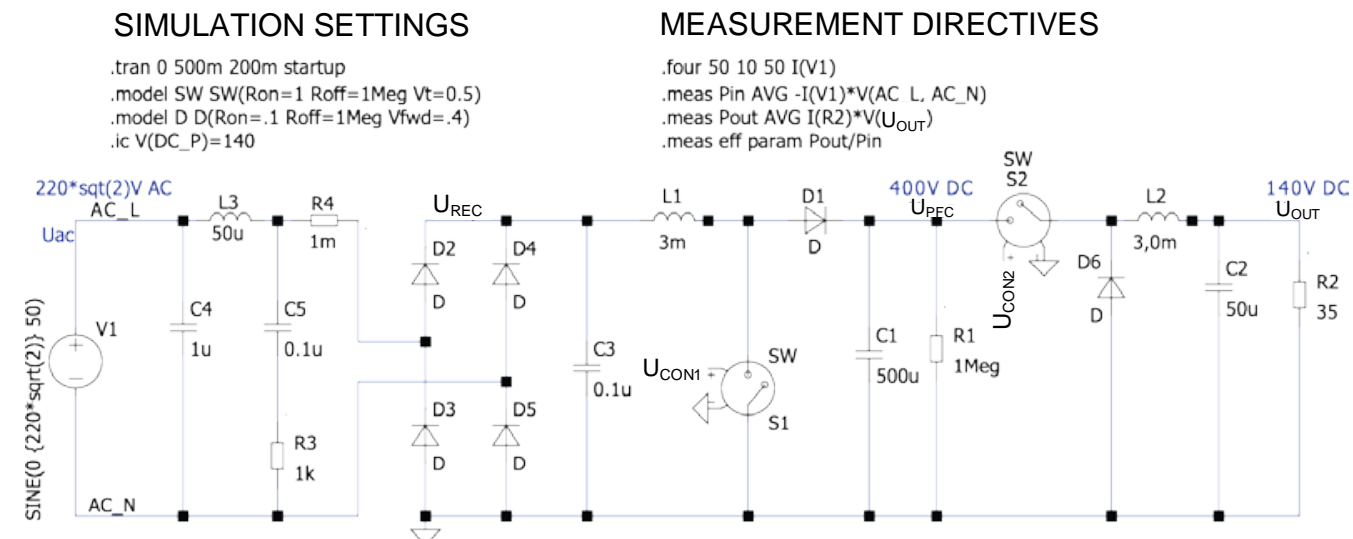

Fig. 11. Model of power supply with PFC and DC converter

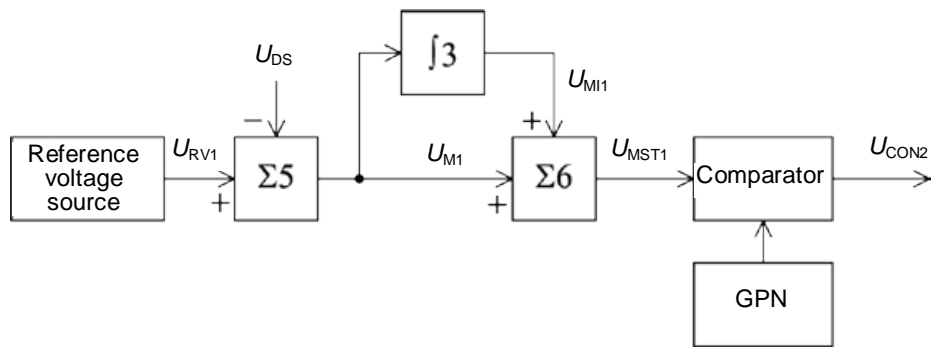

Fig. 12. Functional diagram of the control unit reducing the voltage converter

The PWM signal that controls the power key $S 2$ of the power source $U_{\mathrm{CON} 2}$ (Fig. 10) is generated at the output of the comparator, one of whose inputs is a signal from the output of the sawtooth generator, and the other is a signal from the feedback loop $U_{\mathrm{MST1}}$. The voltage generated at the output of the sixth adder and controls the operation of the pulse-width modulator (PWM modulator) is calculated by the formula: 


$$
U_{\mathrm{MST} 1}(t)=U_{\mathrm{M} 1}(t)+\frac{1}{T_{4}} \int U_{\mathrm{M} 1}(t) d(t),
$$

where $T_{4}$ - time constant of the third integrator of the control unit of the step-down converter.

The carrier frequency of the PWM signal is set by the parameter Tperiod of the pulse generator (Fig. 13).

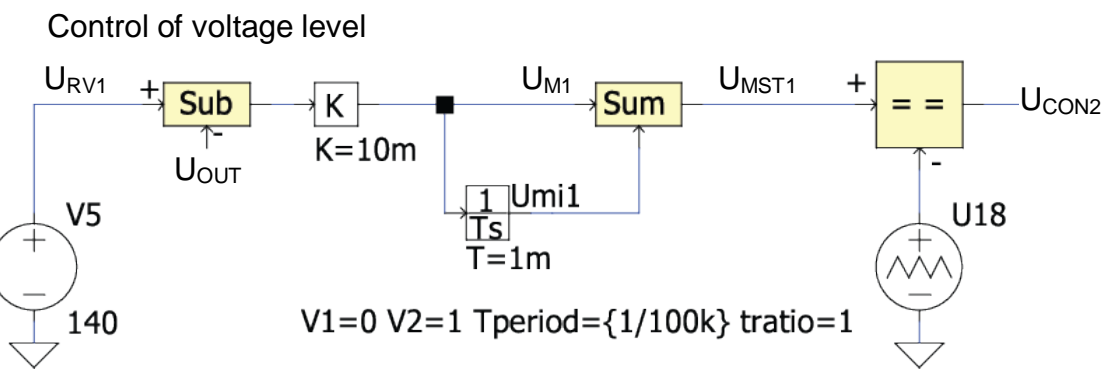

Fig. 13. Model of the control unit of the step-down converter

To study the effect of the switching frequency of the DC converter on the level of conductive interference propagating to the AC network, a fixed switching frequency of the PFC $600 \mathrm{kHz}$ switch was selected, and the switching frequency of the DC switch was varied from 50 to $600 \mathrm{kHz}$ at a fixed resistance of 35 Ohms.

The level of conductive interference was estimated by the level of the highest components in the spectrum of conductive interference, which lie in the frequency range above $1 \mathrm{kHz}$ (Fig. 14).

The dependence of the level of the spectral components of the conductive interference on the switching frequency of the downconverter at a fixed PFC switching frequency key of $600 \mathrm{kHz}$ is shown in Fig. 15.

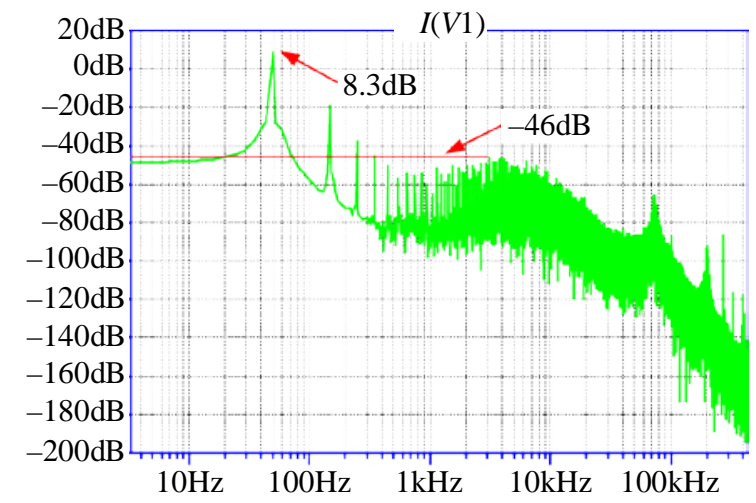

Fig. 14. Spectrum of the current signal of the network at operating frequencies of PFC $600 \mathrm{kHz}$ and the downconverter $100 \mathrm{kHz}$

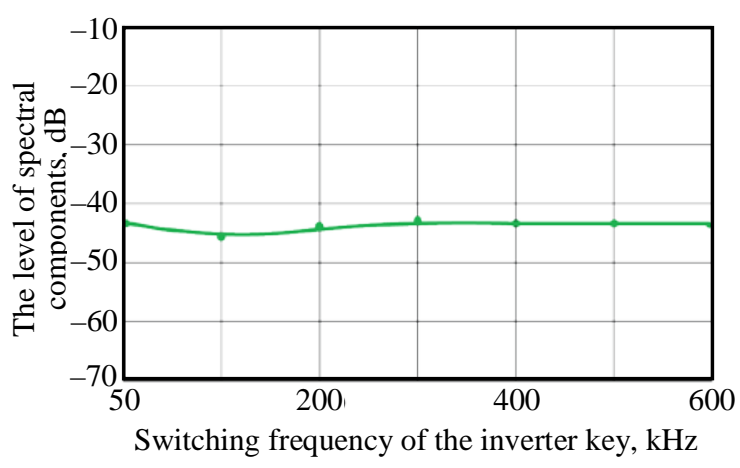

Fig. 15. The dependence of the level of the spectral components of the conductive interference on the switching frequency of the downconverter at a fixed PFC switching frequency key of $600 \mathrm{kHz}$

From the graph in Fig. 15, it follows that a change in the switching frequency of the downconverter key has virtually no effect on the level of conductive interference and may be selected based on design requirements or the presence of an element base.

From [4] it is known that the use of spectrum blur technology can reduce the level of spectral components of conductive noise. For the use of spectrum blurring technology in the downconverter and in the PFC, the pulse generators have been replaced by frequency modulated signal generators with harmonic carrier frequency. 
Only a harmonic signal is provided as a modulating signal in the LTspice environment. But, as shown in [4], the efficiency of the blurring of the spectrum does not depend on the form of the modulating oscillation. For the experiments, a modulation frequency of $2 \mathrm{kHz}$ was selected. The modulation index varied from 2 to 20.

In the study of the effect of the blurring of the spectrum of the signal of the control of the power key in the downconverter, the spectrum with the lowest spectral components at the values of themodulating oscillation frequency of $2 \mathrm{kHz}$ and the modulation index 10. The result is shown in Fig. 16.
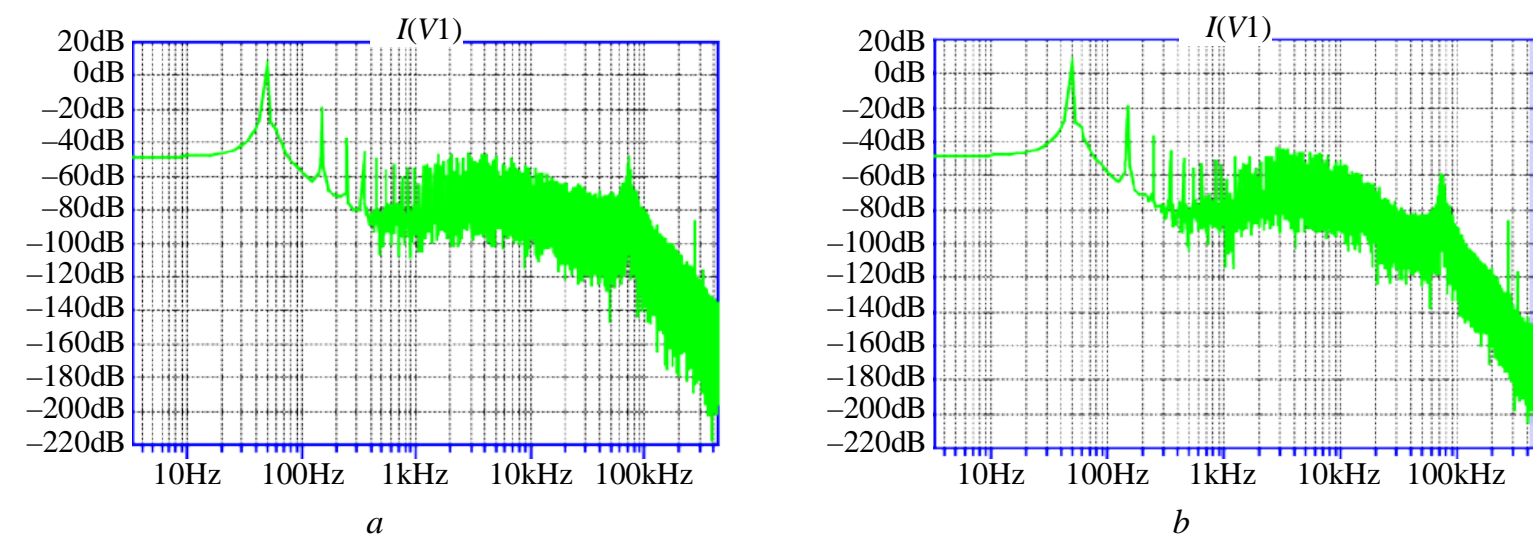

Fig. 16. Spectrum of the current signal of the network at the PFC operating frequency of the $600 \mathrm{kHz}$ and the frequency of the downconverter $200 \mathrm{kHz}$ with a blur of the spectrum (a) and without blur (b) in the down converter

Comparing the spectra in Fig. $16 a$ and $16 b$, it can be concluded that the blurring of the spectrum led to a decrease of the spectral components in the low-frequency part of the spectrum (from 1 to $10 \mathrm{kHz}$ ) by approximately $6 \mathrm{~dB}$, and in the $80 \mathrm{kHz}$ region the level of the components increased by $10 \mathrm{~dB}$.

As the modulation index decreases, the level of the spectral components of the interference increases, and the increase of the index does not lead to changes in the interference spectrum. At a different frequency of the modulating signal, the modulation index, which is optimal in terms of the level of conductive interference, will also change. It is impossible to calculate the modulation index at the selected frequency in such a complex system. Therefore, it should be found at the simulation stage experimentally. A similar study was conducted to test the effectiveness of spectrum blurring in the PFC. The downconverter in this experiment operated at a fixed switching frequency of $200 \mathrm{kHz}$. The best result was obtained with a modulation index of 5 and a frequency of modulating oscillation of $2 \mathrm{kHz}$ (Fig. 17).

Comparing with the spectrum in Fig. $16 b$ (without blurring the spectrum), it can be concluded that the interference components of the interference spectrum decreased by about $5 \mathrm{~dB}$ in the low frequencies, and in the high frequencies the level of the components increased by $4 \mathrm{~dB}$. Using the frequency modulation parameters obtained in the previous experiments, we simulated the operation of a power source with a blurring of the spectrum at both its nodes. The simulation results are shown in Fig. 18. Comparing the obtained spectrum with the spectrum in Fig. $16 a$, it can be concluded that the efficiency of the use of the blur spectrum in both nodes of the power source is about the same as when using the blur spectrum only in the downconverter.

To analyze the influence of the ratio of switching frequencies of the keys of the PFC and the downconverters using the technology of blurring spectrum only in the converter conducted a number of experiments, the results of which are given in Table 2. 


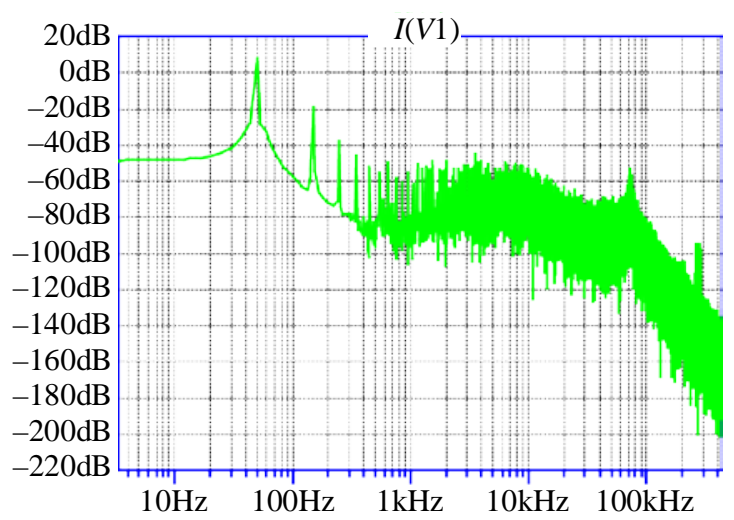

Fig. 17. Spectrum of the current signal of the network at the PFC operating frequency of $600 \mathrm{kHz}$ and the frequency of the $200 \mathrm{kHz}$ downconverter with the blurring of the spectrum in the PFC

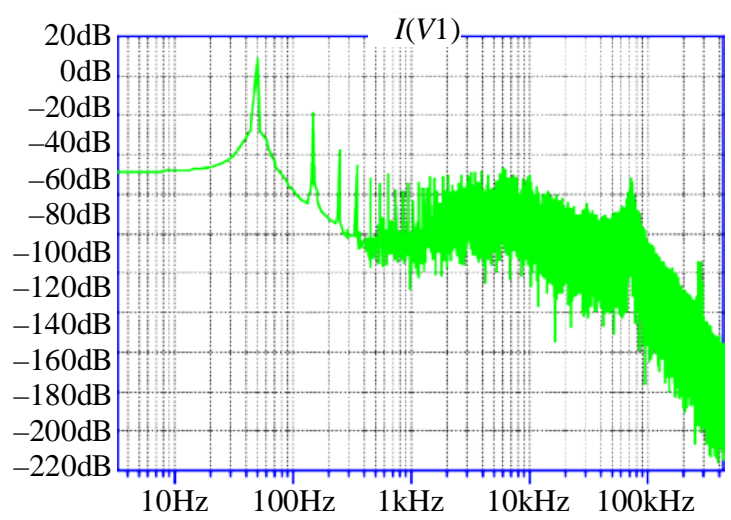

Fig. 18. Spectrum of the current signal of the network at the PFC operating frequency of the $600 \mathrm{kHz}$ and the frequency of the lowering converter $200 \mathrm{kHz}$ with the blurring of the spectrum in the PFC and down converter

Table 2

The dependence of the relative level of conductive noise on the switching frequency of the key in the downconverter when using spectrum blur technology

\begin{tabular}{|c|c|c|c|c|}
\hline \multicolumn{2}{|c|}{ Switching frequency, $\mathrm{kHz}$} & \multirow[b]{2}{*}{$\begin{array}{l}\text { The level of the first } \\
\text { harmonic current of the } \\
\text { AC network, } d B\end{array}$} & \multirow[b]{2}{*}{$\begin{array}{l}\text { The level of the highest } \\
\text { amplitude component of the } \\
\text { spectrum above } 1 \mathrm{kHz}, \mathrm{dB}\end{array}$} & \multirow[b]{2}{*}{$\begin{array}{c}\text { The relative level } \\
\text { of conductive } \\
\text { noise, } \mathrm{dB}\end{array}$} \\
\hline $\begin{array}{l}\text { Power factor } \\
\text { corrector } \\
\text { (PFC) }\end{array}$ & Transformer & & & \\
\hline \multirow{4}{*}{600} & 100 & \multirow{4}{*}{8.3} & -44 & -52.3 \\
\hline & 200 & & -46.7 & -55 \\
\hline & 400 & & -50 & -58.3 \\
\hline & 600 & & -52 & -60.3 \\
\hline \multirow{4}{*}{400} & 100 & \multirow{4}{*}{8.3} & -48.7 & -57 \\
\hline & 200 & & -51.2 & -59.5 \\
\hline & 400 & & -52.5 & -60.8 \\
\hline & 600 & & -54 & -62.3 \\
\hline \multirow{4}{*}{200} & 100 & \multirow{4}{*}{8.3} & -44.9 & -53.2 \\
\hline & 200 & & -46.5 & -54.8 \\
\hline & 400 & & -51 & -59.3 \\
\hline & 600 & & -53.7 & -62 \\
\hline
\end{tabular}

Based on the data of the Table 2 shows graphs of the relative level of conductive interference on the switching frequency of the DC / DC converter key (Fig. 19). The first harmonic current of the AC network is assumed to be $0 \mathrm{~dB}$.

Research results. From the Table 2 of the data it follows that when using the blurring of the spectrum of the key control of the downconverter, there is a pronounced dependence of the relative level of conductive interference on the ratio between the switching frequency of the keys in the PFC and the downconverter. The best results are obtained provided that the switching frequency of the converter is higher than the switching frequency of the key in the PFC. In all experiments, the conductive interfer-

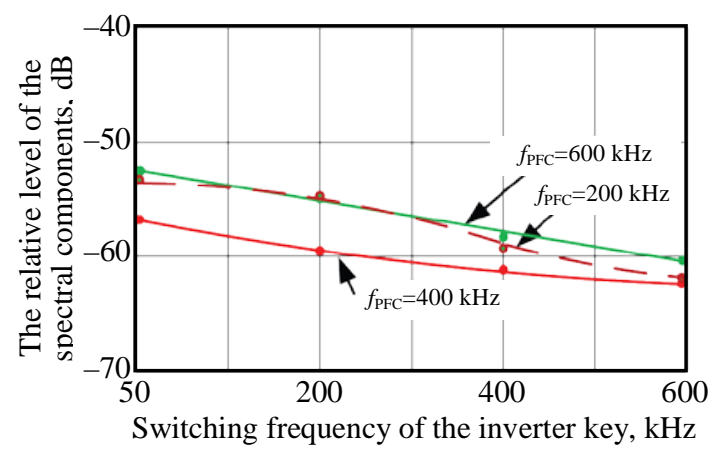

Fig. 19. Dependencies of the relative level of conductive noise on the switching frequency of the DC/DC converter key 
ence level was evaluated relative to the main harmonic current level of the $220 \mathrm{~V} / 50 \mathrm{~Hz}$ of AC network.

\section{Conclusions}

The conducted researches allow to conclude that the level of conductive interferences created by a pulsed AC / DC converter depends both on the switching frequency of the PFC power key and on the ratio of the switching frequency of the PFC power keys and the downlink DC/DC converter.

Selecting the switching frequency of the PFC power key is advisable in two steps. In the first stage, a low switching frequency of the key is set, but not lower than $40 \mathrm{kHz}$ (this is due primarily to the requirements for the mass and dimensions of the PFC inductor coil) and the spectrum of current consumed from the AC network is measured. In the second step, the switching frequency of the key is set in the downward region of the current spectrum, and several iterations of such an experiment are performed to obtain a minimum level of conductive interference.

In order to reduce the level of conductive interference, it is advisable to use the frequency spectrum blurring technology of the signal that controls the transducer key. The choice of modulation index should be made according to the criterion of the minimum level of conductive interference in the low-frequency part of the spectrum.

It is impractical to use spectrum blur in the power factor correction because of poor efficiency.

The choice of switching keys frequency of the PFC and converter should be made by modeling at the given power source parameters to minimize the level of conductive interference when using spectrum blur technology in the converter. The most significant results can be obtained if the converter power switch frequency is greater than the power factor correction key switch frequency. If the blurring of the spectrum is not used, the level of conductive noise is almost independent of the frequency ratio, but it is $8 \ldots 10 \mathrm{~dB}$ higher than in the presence of spectrum blurring.

The use of the proposed methods of minimizing the level of conductive interference can reduce their level by $15 \ldots 20 \mathrm{~dB}$ relative to the interference level of the AC / DC converter without the use of spectrum blur technology and optimization of the switching frequency of the PFC and DC / DC converter keys.

Prospects for further research. With the optimal choice of pulse power supply parameters from the point of view of the level of conductive noise created by it, it is advisable to study the dependence of the level of conductive noise and the efficiency of the source on the speed of switching power keys. The existence of such dependence is known from the publications of Analog Devices. This dependence is nonlinear and has a pronounced minimum of noise at high efficiency. This will reasonably form the requirements for the parameters of the transistors used in the power source.

\section{Література}

1. Котигорошко В. Снижение уровня шумов импульсных стабилизаторов напряжения. Электронные компоненты и системы. 2018. №2. С. 34-41.

2. Браун М. Источники питания. Расчет и конструирование. Киев : МК-Пресс, 2007. 288 с.

3. EMC-Oriented Design of Output Stage of Synchronous Buck Converter / R. Blecic, J. Bacmaga, R. Gillon, etc. 11th International Workshop on the Electromagnetic Compatibility of Integrated Circuits (EMCCompo), 2017. №3. С. 91-96.

4. Макаренко В., Пилинский В. Анализ эффективности использования технологии Spread Spectrum для снижения уровня кондуктивных помех DC/DC-преобразователей. Електротехнічні $i$ комn'ютерні системи. 2017. №24. С. 98-104.

5. Еськин Д. Контроллеры корректоров коэффициента мощности L656x. STMicroelectronics. 2009. URL: https://www.compel.ru/lib/ne/2009/3/6-kontrolleryi-korrektorov-koeffitsienta-moshhnosti-l656x. (дата звернення: 04.11.2019).

6. Войтенко В.А. Расчет 3-Фазного корректора коэффициента мощности с активным выпрямителем. Електротехнічні та комп'ютерні системи. 2019. №30. С. 98-104. 


\section{References}

1. Kotyhoroshko, V. (2018). Noise reduction of impulse voltage stabilizers. Electrical components and systems, 2, 34-41.

2. Broun, M. (2007). Power supply sources. Calculating and design. Kyiv: MK-Press.

3. Blecic, R., Bacmaga, J., \& Gillon, R. et al. (2017). EMC-Oriented Design of Output Stage of Synchronous Buck Converter. International Workshop on the Electromagnetic Compatibility of Integrated Circuits, 3, 91-96.

4. Makarenko, V., \& Pilinsky, V. (2017). Analysis the effectiveness of Spread Spectrum technology to reduce the level of dc/dc converters conducted interference. Electrotechical and computer systems, 24, 98-104.

5. Eskin, D. (2009). Power factor controllers L656x. STMicroelectronics. URL: https://www.compel.ru/ lib/ne/2009/3/6-kontrolleryi-korrektorov-koeffitsienta-moshhnosti-1656x. (Retrieved from: 04.11.2019).

6. Voitenko, V. (2019). Calculating of 3-phase power factor corrector with active rectifier. Electrotechical and computer systems, 30, 98-104.

Макаренко Володимир Васильович, Makarenko Vladimir; ORCID: http://orcid.org/0000-0003-1232-5198

Лукашев Олексій Юрійович, Lukashev Olexy; ORCID: http:/orcid.org/0000-0002-9217-4504

Received November 8, 2019

Accepted December 16, 2019 